\title{
Scale Shifting: New Insights into Global Literary Circulation
}

\section{Introduction}

\author{
Wiebke Sievers \\ Austrian Academy of Sciences, Vienna, Austria \\ wiebke.sievers@oeaw.ac.at \\ Peggy Levitt \\ Wellesley College, Wellesley, MA, USA \\ plevitt@wellesley.edu
}

\begin{abstract}
This special issue on scale shifting brings into sharper focus the complexity of global literary circulation, especially when viewed from the perspective of global literary peripheries. In this introduction, we present the idea of scale shifting, a concept we use to move beyond translation to include circulation in global languages, such as English and French. We build on earlier analyses that mapped previous literary worlds and shed light on the aesthetic and sociological factors that enabled outsiders to enter them by (1) focusing on how peripheralised writers scale up to gain global recognition in multiscalar literary fields and (2) analysing how, in turn, this scale shifting changes the national, regional and global levels of these fields. In addition, we provide a preview of each article included in this volume and summarise the collective takeaways gleaned from our individual case studies.
\end{abstract}

\section{Keywords}

scale shifting - global literary circulation - translation - publishing - literary fields

Franco Moretti once compared the success of Cervantes' Don Quixote with a "classic stone thrown in a pond: it sends out from the Spanish peninsula a series of waves - translation waves, as it were" (Atlas 171). This image wonder- 
fully captures the traditional understanding of literary circulation as a process that begins with the publication and recognition of the respective work in the author's culture of origin followed by a series of translations into other languages that will spread the text to all corners of the globe. This idea of circulation has also become central to the definition of world literature. David Damrosch writes: "I take world literature to encompass all literary works that circulate beyond their culture of origin, either in translation or in their original language" (Damrosch 4). While he is aware that literary circulation is not limited to translation, he nevertheless takes the culture of origin to be the point of departure from which a literary work travels.

We introduce the idea of scale shifting to bring into sharper focus the ways in which global literary circulation is far more complex, especially when viewed from the perspective of global literary peripheries. Books no longer have to be published in New York or London to reach English-speaking readers around the world. In fact, many works in English that circulate widely originate in India and Nigeria because there are enough English-speaking readers to create vibrant national markets of their own. Other works do not start their journey in the context from which their authors write or in their first languages. In a literary world where translations from periperhalised languages were a rarity twenty years ago, when Johan Heilbron first brought the inequality of literary exchange to light, writing in English, French or German is often a first step towards scaling up from a local or national context to a regional literary field. Literary careers, however, are also made the other way around with authors first publishing their works in one of the world literary centres and then scaling down to find recognition back home in the writer's country of origin.

This more nuanced understanding of how and where global literary circulation actually works not only complicates our understanding of a literary work's context of origin. It also makes it more difficult to differentiate between literary centres and literary peripheries. These have become far more entwined since the 196 os but in ways that statistical analyses of translations do not always allow us to see. For instance, the English language still dominates global literary circulation, but the books recognised as literature in English are far more diverse in terms of where they are written and who writes them than seventy years ago, even if the percentage of translations published in English remains unchanged. This is because, more and more, peripheralised authors writing in English as well as immigrants and their descendants in Great Britain and the United States are included in the "literature written in English" category.

The contributors to this special volume map the political, economic, and cultural factors that affect scale shifting by building upon earlier analyses that 
began to spell out the aesthetic and sociological factors that enabled outsiders to get recognised and travel (Casanova; Bourdieu). Our contributors move these conversations forward by focusing on how peripheralised writers scale up to gain global visibility in multiscalar literary fields and the ways in which this scale shifting transforms the national, regional and global levels of these fields.

Our introduction proceeds as follows. We first say a bit about our terminology before reviewing the literature with which we are in conversation. We then provide a preview of each article and summarise what we have learned.

\section{Scale Shifting in the Multiscalar Global Literary Field}

Cultural studies and literary scholars, as well as sociologists analysing taste, fame, and distinction, work with the idea of fields. They are as interested in individual cultural producers as they are in the organisations and networks that constitute the social fields in which they operate. They want to understand boundary making or how we differentiate one field from another and how actors within these fields claim and protect their positions (Lamont and Molnár). Bourdieu defined fields as social spaces of relations that are characterised by competition over resources and capital. Actors, whose positions, cultural stances, and identities fluctuate, vie for positions according to the implicit or explicit rules of the game (Go and Krause; Bourdieu and Wacquant). More powerful actors establish these rules, protecting their positions by designating some forms of capital as more valuable than others. According to Go and Krause, "struggle and hierarchy are not only characteristic of fields, they also form the basis for many of the processes and logics of fields themselves" (10). Fields achieve different levels of autonomy that change over time depending upon how strongly and frequently they are linked to other fields (Fligstein and McAdam).

With regard to literary fields, relative autonomy implies freedom from, on the one hand, religious and/or state control through censorship and repression and, on the other hand, market demands that favour works produced in literary centres as well as bestsellers in standardised genres such as crime fiction (Sapiro "Literary Field"; Sapiro "Autonomy"). A central struggle in literary fields therefore concerns the differentiation between those authors, publishers and critics who submit to religious, political or economic constraints - or to use Bourdieu's term, those who are heteronomous - from those who operate more autonomously by only responding to the literary norms and the judgements of their peers. Only those "autonomous" authors are regarded as writing litera- 
ture. This means that what qualifies as literature is not defined objectively but, rather, is the result of an ongoing struggle about who is an autonomous writer within the respective literary field. What is regarded as literature thus changes over time and differs across space.

Buchholz draws our attention to fields of different scales and their autonomy in relation to each other. She defines global fields as spheres of specialised practice that operate on a transcontinental scale. They are produced by global institutions that function across borders and by the articulation of a field specific discourse. They also operate according to unique metrics of evaluation and critique or ways of talking about, writing about, valuing, and categorizing this global cultural space. Global fields differ from their national counterparts because of their function and by the space in which they operate. Their agents have different interests, use different practices, and follow different logics. In short, Buchholz writes, "a multi-scalar global field can be defined as a globally extended sphere of specialised practice that displays a relatively autonomous logic of competition vis-à-vis other types of fields as well as other field levels within the same realm of practice" (42).

Buchholz developed her model based on the global art world. However, there is some evidence that the global literary field is structured in a similarly multiscalar way. Pascale Casanova was the first to describe a global literary field that was distinct from its national literary counterparts. She conceived of this "World Republic of Letters" as allowing authors from around the world to achieve greater autonomy vis-à-vis the limiting frameworks of national literary fields. Casanova argues that authors and their works scale up from the national to the global level by using styles, genres or content which are valued beyond their national context. They combine cultural capital from their national field with cultural capital that is valued globally by writing in a language with a long and globally recognised literary history, such as English or French, or by adopting literary forms from globally recognised literary traditions. All literary fields, she argues, have a national and international pole.

Pierre Halen takes this model further in his analysis of Francophone literary fields. He identifies three to four levels of circulation: the local level, the Francophone level and the global level with sometimes an additional regional level between the local and the Francophone, such as the Caribbean or the Maghreb. Drawing on these observations, we differentiate between three levels of circulation: the national, the regional and the global. The regional in this context refers to levels of circulation beyond the national, but below the global. Such circulation may take place in one language, as in the case in the Anglophone or the Arabophone region, or in translation, for example, in the Asian region. If we believe Buchholz, competition works differently on all of these levels. In 
other words, we need to understand the rules of the game within and between these levels to understand global literary circulation.

The main aim of this special issue is to understand the conditions that allow authors from what have been peripheral countries to scale up and gain global literary attention since the 196os and the extent to which these processes of scale shifting have transformed literary fields. This interest is rooted in our firm belief that intellectual and cultural inequality must be addressed, in the same way that socioeconomic inequalities must be remediated. We also believe strongly in literature's power to liberate or, as Pheng Cheah writes, in its "power or efficacy to change the world according to a normative ethicopolitical horizon" (6). Cheah argues that writers working from the periphery have a particularly important role to play in righting cultural wrongs because they feel globalisation's effects more powerfully than writers working from economic or cultural centres. Because the hierarchies of multiscalar literary fields favour those writing from more advantaged positions, however, it is far more difficult for peripheral authors to gain global literary recognition. They are, therefore, left out of the conversation about the literary representation of the world.

What socioeconomic and cultural conditions and relations of power would allow things to work differently? The answer requires taking into consideration the perspective of authors writing from literary peripheries but also understanding the extent to which Western literary fields have been transformed by their encounters with these writers. Our contributors speak to both sides of these important questions - Markus Arnold, Tristan Leperlier, Alvaro SantanaAcuña and Jessica Siu-yin Yeung discuss scale-shifting from the perspective of peripheralised authors while Gisèle Sapiro, Wiebke Sievers and Marcella Rutherford and Peggy Levitt analyse changes in Western literary fields. Sonja Mejcher-Atassi's summary response takes us beyond this empirical work on how global literary circulation has changed over the last decades by raising fundamental questions about who world literature is for and how we might move forward to foster truly inclusive and more egalitarian exchanges.

In the volume's opening article "The transnational literary field between (inter)-nationalism and cosmopolitanism" Gisèle Sapiro traces the broad arc of when and how the multiscalar global literary field emerged and of the ways in which it has evolved over time. Sapiro calls this field "transnational" to drive home the fact that significant parts of the world, in particular Africa, are not yet incorporated into it. She points out that the export of European literary works 
to the colonies and their import in many other countries has been central to the emergence of a worldwide map of national literatures linked by literary circulation in the nineteenth and twentieth centuries. After World War I, the International Committee on Intellectual Cooperation of the League of Nations and the PEN-Club institutionalised the discourse of international literary exchange as a core value that would check the nationalist xenophobia that caused the war. From the beginning of the field's emergence in the nineteenth century, there were some literary works circulating in many national literatures. The consecration of some of these works was institutionalised in the Nobel Prize in 1901 and by the 1950s, there was a global literary canon of works by European and North American authors.

Only after World War II, the successor of the International Committee on Intellectual Cooperation of the League of Nations, UNEsco (The United Nations Education, Science, and Cultural Organisation), initiated a project aimed at expanding literary circulation beyond the European centre. This project has contributed enormously to allowing peripheralised authors to scale up and receive global literary recognition, which Sapiro illustrates using the example of the French literary field. Nevertheless only a few authors writing in peripheralised languages, such as Arab or Chinese, have achieved global literary recognition to date. Since the 1970s, we see increasing efforts to include more women and minorities. Despite increasing diversity, however, the agents and publishers who drive these developments and who benefit from them are still primarily located in Western literary centres, namely New York, London and Paris.

Marcus Arnold and Tristan Lepelier's contributions analyse multiscalar literary fields from the perspective of writers working from the periphery. In his article "Moving between Mauritius and the World (or not)" Arnold argues that contemporary Mauritian literature circulates at four levels: the multilingual local level which is dominated by the French language; a very limited Southto-South circulation; publication in France; and circulation in translation on the global level. He writes that those texts which are able to scale up to achieve global recognition share two features. They discuss the concerns of this small post-colonial island in terms of neoliberal globalisation which is recognisable across the globe and they do not use many multilingual references so they are easier to translate into other languages. The post-colonial turn in France, since 200o, has also contributed to their recognition. In addition, these texts received boosts from French institutions working in Mauritius and from French authors, such as Noble Prize winner J.M.G. Le Clézio, who has family links to the island. The growing recognition of Mauritian authors in France has also increased the autonomy of the local Mauritian literary field. Those recognised abroad can 
no longer be censored at home and, therefore, are making important contributions to combatting sociopolitical and ethnocultural conservatism. Moreover, some recognised authors have actively taken on the cause of making local writing more visible by opting to publish with local publishers.

Tristan Leperlier uses the case of the transnational Algerian literary field to analyse the long-term relations between its national and international poles. He questions the bipolar opposition proposed by Pascale Casanova that classifies its international level as autonomous and the national as heteronomous. This opposition first emerged in the early twentieth century, and while it has long characterised the relationship between the two poles of the field, Leperlier argues that we need a more nuanced view. Algerian writers fled to France and published there to escape the many constraints they faced at home where publishing was a monopoly of the state. Their works were banned in Algeria and the authors criticised as traitors of the country. Leperlier shows how this bipolar opposition, however, has become increasingly blurred since the 1970s. While in Algeria, the government relaxed political repression and the first private publishing houses emerged, in France, the literary field became more and more beholden to economic pressures that forced authors to adapt to the demands of the market. Over the course of the civil war, the works of writers such as Yasmina Khadra, who openly supported anti-Islamist efforts in Algeria, circulated widely in the French literary field where anti-Islamism was on the rise. Their colleagues in Algeria, such as Kamel Daoud, criticised these authors for writing in a way that pandered to economic and political demands. After the civil war, however, these authors also scaled up and became recognised in France. At the same time, literary actors in Algeria assimilated some of the more diverse understandings of their country that coalesced during the war in France and used them to create a more diverse literary field in Algeria.

Our next contributors look closely at the mechanisms and conditions that allow scale shifting to take place. The article "Intermedial Translation as Circulation: Chu Tien-wen, Taiwan New Cinema, and Taiwan Literature" shows how the author Chu Tien-wen used the intermedial translation of literature into film as a scale shifting strategy. Jessica Siu-yin Yeung argues that the New Cinema Period in Taiwan (1982-199o) helped to create a national literature that operates relatively autonomously from Chinese literature and state repression in Taiwan and is internationally recognised. Central to this development were collaborative projects of filmmakers and authors who acted as scriptwriters. At the time, film was the most favourable medium for the circulation of narratives that opposed the official ideology imposed by the Taiwanese authoritarian regime because censorship regulations were less strict for film than literature. Moreover, the worldwide network of film festivals were key to bring- 
ing Taiwanese films, and later literature, into the spotlight. From 1983 onwards, the collaborative works of author Chu Tien-wen with filmmaker Hou Hsiaohsien scaled up from national to global recognition. Indeed, in 1989, The City of Sadness won the Golden Lion Award at the Venice International film festival. When this film, which was quite critical of the regime, scaled down and became popular in Taiwan as a result, it was an important turning point for the establishment of an autonomous field of art in Taiwan. The Taiwanese government has since supported the international circulation of film and literature and Chu Tien-wen has become a consecrated author not only in Taiwan but also abroad.

Alvaro Santana-Acuña's "Aesthetic Labeling and Scale Shifting in Cultural Production and Circulation" highlights the importance of literary labelling as a strategy for peripheralised authors seeking increased global literary recognition. Bourdieu mentioned labels, such as naturalism or symbolism, as important marks of distinction in the struggle for recognition in national literary fields $(126-127 ; 157)$. Santana-Acuña shows that peripheralised authors increase their chances of scaling up to global literary recognition if they cooperate in the creation of a supra-national tradition under a joint label. He uses the case of Latin-American literature to make his point. The creation and promotion of a style called magical realism under the label Latin-American literature led to the massive upscaling of authors from more than twenty countries in what became known as the Latin-American boom in the 196os. The invention of this tradition began in the 1920 s and resulted from a 40-year collaborative effort between three generations of authors, critics, publishers, journal editors, and conference organizers. The label Latin-American literature gained in importance both in the region and beyond in the 196os when authors identified with the category scaled up to global recognition. It is this long history that explains the enormous success of Gabriel García Márquez's One Hundred Years of Solitude published in 1965 . Prior to this novel, Márquez had written in a regional style. One Hundred Years of Solitude, in contrast, was intentionally written in the Latin American tradition to rise on the winds of this label that was gaining in prominence at the time of its publication. A similar argument, Santana-Acuña writes, can be made about the subsequent scale shifting of many post-colonial writers.

The final two contributions to our volume analyse the incorporation of peripheralised authors in the Western literary centres. In "Globalising the West" Wiebke Sievers discusses the upscaling of immigrants and ethnic minorities in Western literary fields since the 196os as an international process related to the more general recognition of non-Western writers as well as to the emergence of regional literary fields. She argues that immigrants and ethnic minorities 
were particularly successful in gaining visibility when their upscaling coincided with other effects of globalisation on literature, i.e. the growing recognition of authors residing in literary peripheries and/or the growing exchange between literary fields operating in the same language. The recognition of immigrants and ethnic minorities in Western literary fields has a long history reaching back as far as the Harlem Renaissance beginning in the 1920 s and the Négritude Movement in 1930s France. International protests in the 196os, that began with the Civil Rights Movement in the United States, initiated a more profound process of change regarding the inclusion of minorities and immigrants in literary fields. The effects of these changes are most pronounced in contexts, such as Britain, where the scaling up of English literary works from the former colonies prepared the ground for the later recognition of (post-)colonial immigrants and their descendants as British writers. In the German context, in contrast, these are also simultaneous processes, albeit often regarded as unrelated. There is an increasing recognition of peripheralised authors mainly through the translation of English and French postcolonial writers into German. The first immigrants to find recognition as writers, by contrast, are mainly of Italian and Turkish origin and focus on growing labour immigration to Germany from their countries of origin. This gap between the different processes of globalisation explains the far slower process of upscaling of these authors in the German literary field.

The publication and critical reception of peripheralised writers is only the first step in the long process of authors scaling up to recognition. For a more enduring change in Western literary fields these authors also need to enter the pedagogical literary canon. Markella Rutherford and Peggy Levitt analyse literary anthologies and courses taught at universities to assess if and how far pedagogical canons have changed in the United States. Their findings show that the turn towards world literature in literary studies in the United States has already had a positive effect on teaching. Professors have increasingly shifted to including a more global selection of authors in their literature courses at the same time that editors of comparative and world literature anthologies are including more diverse materials in their texts - dual processes which drive each other forward in a mutually beneficial way. There was steady movement away from "the West is World paradigm" toward "the West and the Rest" to the current more "Global integration paradigm." This did not, however, translate into greater inclusion in the broader curriculum. Their analysis of a publicallyavailable database of over 20,000 syllabi showed that for the most-assigned texts of Western and non-Western authors, the median teaching score (i.e. how often these texts were assigned) for Western texts is still substantially higher than the median for non-Western texts: 39 versus 8.9. 
Finally, Sonja Mejcher-Atassi reminds us that, in spite of these many steps forward, there is still a great deal of work to be done. The West still lies at the centre of global literary circulation where all the main publishing houses are located and most decisions get made. Mejcher-Atassi leaves us with the charge to keep these inequalities in sight and to make sure that our teaching and research remediate them.

\section{3}

\section{The Rules of Art in Multiscalar Global Literary Fields}

The contributions to this special issue illustrate that, since the 196os, global literary fields have increasingly come to include peripheralised writers. They bring to light the socioeconomic conditions that make these changes possible. It is not just the brilliance of individual authors, such as Gabriel García Márquez or Salman Rushdie (although this certainly helps) but the efforts by several generations of authors and institutions across several national spaces that make scale shifting possible. These continued, collective projects have, little by little, forced publishers, critics and academics in the centres of the literary world to make room for more peripheralised writers and for writers of immigrant and ethnic minority backgrounds as well. What have we learned about the rules of art in multiscalar global literary fields? And how do these rules influence the upscaling of peripheralised authors to global recognition?

Casanova argued that operating at the global level of the World Republic of Letters allows authors to move beyond the limitations of national literary fields. Indeed, overcoming the national has been a major incentive for the emergence of world literary studies: "The point is that there is no other justification for the study of world literature [...] but this: to be a thorn in the side, a permanent intellectual challenge to national literatures - especially the local literature." (Moretti "Conjectures" 68). Others call authors who circulate globally traitors to the national cause. They see them as giving in to Western demands for exotic writing from the literary peripheries. Thus, Pierre Halen and Graham Huggan argue that writers, like Salman Rushdie or Tahar Ben Jelloun, present India and the Maghreb as foreign and mysterious to get publishers and critics in London and Paris interested in their work. At best, scholars see authors like these as strategically pulling the wool over the West's eyes as a means to then criticise Western hegemony in their literary works. At worst, these authors are criticised for misrepresenting their countries to achieve greater symbolic or economic gains. As Halen writes about Ben Jelloun, his friends in the Maghreb cannot even recognise themselves in his works (67). 
Rather than positioning the national and global in opposition to each other, we believe a transnational optic helps us to better uncover the rules of the game within multiscalar fields (Levitt 145; Khagram and Levitt). Doing so, allows us not to privilege one scale over the other but to hold all levels of literary production in conversation with one another and to study the interaction between them. Such a view reveals that each scale faces its own unique barriers to greater literary diversity. At the national level, these include political factors like censorship, but also ideologies about homogenous nations that favour specific groups. Global literary circulation, in addition to being a corrective to nationalistic xenophobia, affords authors a space within which they can manoeuvre and evade political pressures (Sapiro "Literary"). Greater literary diversity is also blocked at the global level because power in the global publishing industry is increasingly concentrated in the hands of a few conglomerates whose bottom line is profit (Thompson). While there have been global initiatives to counter this trend, such as the 2005 UNESCO Convention on Cultural Diversity, the most important actors guaranteeing global diversification are small publishing houses who operate primarily at the national level. They are the bright spots in national literary fields in places such as the United States, France and Britain where what gets published by larger companies is increasingly determined by what will sell (Thompson 394-402; Sapiro "Globalization"; Sievers 41-49). In other words, it is that combination of global and national level factors that guarantees relative autonomy from economic and political pressures and thus allows for the continued diversification of the global literary field.

Peripheralised authors use the dynamics between these levels as tools in the struggle for autonomy and attention. The global space has a long history of being such a lever for achieving greater political autonomy. Paris became the city where innumerable writers moved from the nineteenth century onwards to avoid persecution at home (Casanova). It became a place where authors who were marginalised in their homelands could express themselves freely. Moreover, political autonomy also became institutionalised as a central value as early as 1921, when John Galsworthy first established PEN International in London. At that time, censorship was a major issue and organizing internationally was seen as a strong, effective tool for fighting it at the national level. A decade later, the fight for freedom of speech became one of PEN's central concerns when German National Socialists revoked the citizenship of many writers. Clearly, national laws alone could not guarantee writers' rights. "Literary texts, now tied to the fate of authors, required international protection from state suppression" (Potter 77).

Our contributions show that, unfortunately, these same concerns resonate today. Gaining recognition outside one's nation of origin is still an important 
strategy for writers to overcome censorship or sociopolitical and ethnocultural conservatism back home. One example is the literary career of Ananda Devi who is considered the Grande Dame of the Mauritian literary world today. As Arnold explains, she began her career as a writer not in Mauritius but with Nouvelles Éditions Africaines (NEA), a Dakar-Lomé-Abidjan based publisher. Her first novel, Rue La Poudrière, which dealt with the precarious and miserable lives of prostitutes in Mauritius would undoubtedly have met with resistance at home. Even when she got published with NEA, it was not enough to overcome the public's reservations about her writing in her country of origin. It was only after her next two novels were favourably received in Paris that her first novel was republished on the island.

The struggle for political autonomy has also become a form of cultural capital valued by those involved in the recognition of authors. Jessica Yeung argues that the many international prizes awarded to Taiwanese films were, in part, given because they were associated with the country's turn toward democracy. One reason why A City of Sadness won the Golden Lion at the Venice Film Festival, for example, is that it addresses the purges executed by the authoritarian regime in 1948. When these authors scale down, be it in Mauritius or in Taiwan, they do so with enhanced autonomy.

But the power and possibility generated by working at the interstices between the national and the global does not always wield positive results. An example is Nawal El Saadawi, an Egyptian writer, who gained prominence in the 1970s as part of the larger anti-imperialist and feminist movements in the Arab world. Like many of her colleagues at the time, she suffered from repression before she went into exile in the United States. Her English translators and critics later praised her as the exceptional voice in a repressive Islamic regime pigeonholing her and using her as gratuitous proof that this part of the world could produce writers of another ilk (Amireh). Arab writers, in particular, are often slotted somewhere within this false binary between the liberal West and the repressive Orient. We write at a moment of striking illiberalism and heightened nationalism in the West - at a time when the political autonomy of many writers in the Global North is also under threat. This underscores, for us, the continuing importance of the global scale in protecting political and intellectual freedom for writers everywhere. Finally, our cases demonstrate that the hierarchy between the national and international poles of literary fields are not fixed. The Algerian case is one in which authors on the national pole of the field managed to gain recognition by criticizing their compatriots succeeding in France for selling themselves to the French public. If this is the case, why should it not be possible to reorder the hierarchy between central and peripheralised fields? 


\section{Acknowledgements}

The articles published in this special issue were presented at a conference at the University of Vienna in December 2017. We would like to thank the following institutions for their generous support for this event: the Commission for Migration and Integration Research and the Institute of Urban and Regional Research of the Austrian Academy of Sciences; Wellesley College; the IMISCOE standing committee Popular Art, Diversity and Cultural Policies in PostMigration Urban Settings (POPADIVCIT), now called DIVCULT (Superdiversity, Migration, and Cultural Change) and the research platform Mobile Cultures and Societies of the University of Vienna.

\section{Works Cited}

Amireh, Amal. "Framing Nawal El Saadawi: Arab Feminism in a Transnational World." Signs 26:1 (2000), 215-49.

Bourdieu, Pierre. The Rules of Art: Genesis and Structure of the Literary Field. Trans. Susan Emanuel. Cambridge: Polity Press, 1996.

Bourdieu, Pierre, and Loic J.D. Wacquant. An Invitation to Reflexive Sociology. Chicago: University of Chicago Press, 1992.

Buchholz, Larissa. "What Is a Global Field? Theorizing Fields Beyond the Nation-State." The Sociological Review Monographs 64:2 (2016), 31-6o.

Casanova, Pascale. The World Republic of Letters. Trans. M.B. DeBevoise. Cambridge: Harvard UP, 2004.

Cheah, Pheng. What Is a World? On Postcolonial Literature as World Literature. Durham: Duke UP, 2016.

Damrosch, David. What Is World Literature? Princeton: Princeton UP, 2003.

Fligstein, Neil, and Doug McAdam. A Theory of Fields. Oxford: Oxford UP, 2012.

Go, Julian, and Monika Krause. "Fielding Transnationalism: An Introduction." The Sociological Review Monographs 64:2 (2016), 6-30.

Halen, Pierre. "Notes pour une topologie institutionnelle du système littéraire francophone." In Littératures et sociétés africaines: regards comparatistes et perspectives interculturelles:mélanges offerts à János Riesz à l'occasion de son soixantième anniversaire. Eds. Papa Samba Diop et al. Tübingen: Narr, 20o1, 55-68.

Heilbron, Johan. "Towards a Sociology of Translation: Book Translations as a Cultural World-System." European Journal of Social Theory 2:4 (1999), 429-44.

Huggan, Graham. The Postcolonial Exotic: Marketing the Margins. London: Cambridge UP, 2001.

Khagram, Sanjeev, and Peggy Levitt. “Constructing Transnational Studies." In The Trans- 
national Studies Reader. Eds. Sanjeev Khagram and Peggy Levitt. New York: Routledge, 2007, 1-18.

Lamont, Michèle, and Virág Molnár. "The Study of Boundaries across the Social Sciences." Annual Review of Sociology 28 (2002), 167-95.

Levitt, Peggy. "Global Culture in Motion." In Global Culture: Consciousness and Connectivity. Eds. Roland Robertson and Didem Buhari-Gulmez. Farnham: Ashgate, 2015, 143-6o.

Moretti, Franco. Atlas of the European Novel 180o-19oo. London: Verso, 1998.

Moretti, Franco. “Conjectures on World Literature." New Left Review 1 (2000): 54-68.

Sapiro, Gisèle. "Autonomy Revisited: The Question of Mediations and its Methodological Implications.” Paragraph 35:1 (2012), 30-48.

Sapiro, Gisèle. "Globalization and Cultural Diversity in the Book Market: The Case of Literary Translations in the US and in France." Poetics 38:4 (2010), 419-39.

Sapiro, Gisèle. "How Do Literary Works Cross Borders (or Not)? A Sociological Approach to World Literature." Journal of World Literature 1:1 (2016), 81-96.

Sapiro, Gisèle. "The Literary Field between the State and the Market." Poetics 31:5-6 (2003), 441-64.

Sievers, Wiebke. Contemporary German Prose in Britain and France (1980-1999): A Case Study of the Significance of Otherness in Translation. Lewiston: Edwin Mellen Press, 2007.

Thompson, John B. Merchants of Culture. The Publishing Business in the Twenty-First Century. Cambridge: Polity Press, 2010. 